\title{
RE-EVALUASI HUBUNGAN PENGAWASAN PUSAT DAN DAERAH SETELAH BERLAKUNYA UU NO. 23 TAHUN 2014 TENTANG PEMERINTAHAN DAERAH
}

\author{
Agus Kusnadi \\ Fakultas Hukum Universitas Padjadjaran Bandung \\ J1. Dipati Ukur No. 35 Bandung \\ Email: aguskusnadi63@yahoo.com
}

\begin{abstract}
The Indonesian Constitution states the presence of Government Affairs which is the full authority of the Central Government or absolute government affairs and concurrent. Concurrent affairs consisting of Government Affairs Mandatory are divided between the national, local, provincial and cities. As for Article 18 paragraph (5) of the 1945 Constitution, Regional Government run broad autonomy. This study examines the relationship with the supervision of the implementation of wide-ranging autonomy. The research problems are: First, to examine and analyze the implementation of supervisory relationship to the Regional Centre associated with the implementation of broad autonomy after the enactment of Law No. 23 Year 2014 on Regional Government. Second, to examine and analyze the arrangement of the Central and Local Governement in Law Number 23 Year 2014 on Regional Government which is in conjunction with the region's autonomy.

The method used in this research is normative, while the data analysis techniques used is qualitative and descriptive analysis. The result of this research shows that there is a political development in the field of Local Government, especially regarding monitoring of the Regional Centre adopted and implemented after the enactment of Law No. 23, 2014. The results shows that the guidance and supervision of the organization of local government, as stipulated Law No. 23 Year 2014 in implementation does not reduce or not handcuff local independence, and certainly not hinder development in the area.
\end{abstract}

Key words: monitoring, national, local, deconsentration and local government law

\begin{abstract}
Abstrak
UUD NRI Tahun 1945 menentukan adanya Urusan Pemerintahan yang sepenuhnya menjadi kewenangan Pemerintah Pusat yang dikenal dengan istilah urusan pemerintahan absolut dan ada urusan pemerintahan konkuren. Urusan pemerintahan konkuren terdiri atas Urusan Pemerintahan Wajib dan Urusan Pemerintahan Pilihan yang dibagi antara Pemerintah Pusat, Daerah provinsi, dan Daerah kabupaten/kota. Adapun Pasal 18 ayat (5) UUD NRI Tahun 1945 mengatur bahwa Pemerintahan Daerah menjalankan otonomi seluas-luasnya. Oleh sebab itu, dalam tulisan ini dikaji hubungan pengawasan dengan penyelenggaraan otonomi luas. Fokus permasalahan penelitian ini adalah: Pertama, untuk mengkaji dan menganalisis hubungan pengawasan Pusat terhadap Daerah dikaitkan dengan penyelenggaraan otonomi luas setelah berlakunya Undang-Undang Nomor 23 Tahun 2014 tentang Pemerintahan Daerah. Kedua, untuk mengkaji dan menganalisis pengaturan hubungan Pusat dan Daerah dalam UndangUndang Nomor 23 Tahun 2014 tentang Pemerintahan Daerah dalam hubungannya dengan
\end{abstract}


kemandirian daerah. Metode penelitian yang digunakan dalam penelitian ini adalah yuridis normatif. Sementara itu, teknik analisis data yang akan digunakan adalah teknik analisis secara kualitatif dan deskriptif, sehingga penelitian ini termasuk penelitian yuridis normatif dengan kajian deskriptis-kualitatif. Berdasarkan hasil penelitian ini diketahui bahwa perkembangan politik hukum baru di bidang Pemerintahan Daerah, khususnya tentang pengawasan Pusat terhadap Daerah yang dianut dan diterapkan setelah berlakunya Undang-Undang No. 23 Tahun 2014. Hasil penelitian menunjukkan bahwa pembinaan dan pengawasan terhadap penyelengaraan pemerintahan daerah sebagaimana diatur dalam UU No. 23 Tahun 2014 dalam pelaksanaannya tidak mengurangi atau tidak membelenggu kemandirian daerah serta tentu saja tidak menghambat pembangunan di daerah.

Kata kunci: hubungan pengawasan, pusat, daerah, pemerintahan daerah

\section{Latar Belakang}

Pembentukan Undang-undang Nomor 23 Tahun 2014 tentang Pemerintahan Daerah mengakibatkan beberapa perubahan di dalam model pengaturan dan system pemerintahan tentang pemerintahan daerah. Undang-undang Nomor 23 Tahun 2014 tentang Pemerintahan Daerah tidak mengatur tentang pemerintahan Desa dan tentang Pemilihan kepala daerah (pemilukada) karena telah diundangkan tersendiri dalam Undang-undang No. 6 Tahun 2014 tentang Desa dan Undangundang tentang Pemilukada. Berkaitan dengan penyelenggaraan pemerintahan daerah, Undang-undang Nomor 23 Tahun 2014 menyebutkan bahwa DPRD dan kepala daerah berkedudukan sebagai penyelenggara pemerintahan daerah yang diberimandat rakyat untuk melaksanakan Urusan Pemerintahan yang diserahkan kepada Daerah. DPRD dan kepala daerah berkedudukan sebagai mitra sejajar dengan mempunyai fungsi yang berbeda. ${ }^{1}$
Kepala daerah melaksanakan fungsi pelaksanaan atas Peraturan Daerah (yang selanjutnya disebut Perda) dan kebijakan Daerah sedangkan DPRD mempunyai fungsi pembentukan Perda, anggaran (budgeting) dan pengawasan (controlling). Dalam pembentukan Perda menurut UU No 23 Tahun 2014, harus selalu di bawah pengawasan Pemerintah Pusat, dalam hal ini Presiden sebagai penanggung jawab akhir seluruh penyelenggaraan pemerintahan secara nasional. Dalam mengatur dan mengurus Urusan Pemerintahan yang menjadi kewenangan Daerah tersebut, DPRD dan kepala daerah dibantu oleh Perangkat Daerah. Sebagai konsekuensi posisi DPRD sebagai unsur penyelenggara Pemerintahan Daerah maka susunan, kedudukan, peran, hak, kewajiban, tugas, wewenang, dan fungsi DPRD tidak diatur dalam beberapa undang-undang namun cukup diatur dalam Undang-Undang ini secara keseluruhan guna memudahkan pengaturannya secara terintegrasi. 
Sebagaimana diamanatkan oleh UndangUndang Dasar Negara Republik Indonesia Tahun 1945, terdapat Urusan Pemerintahan yang sepenuhnya menjadi kewenangan Pemerintah Pusat yang dikenal dengan istilah urusan pemerintahan absolut dan ada urusan pemerintahan konkuren. Urusan pemerintahan konkuren terdiri atas Urusan Pemerintahan Wajib dan Urusan Pemerintahan Pilihan yang dibagi antara Pemerintah Pusat, Daerah provinsi, dan Daerah kabupaten/kota. Adapun Pasal 18 ayat (5) UUD 1945 menyebutkan Pemerintahan Daerah menjalankan otonomi seluas-luasnya. Oleh sebab itu, dalampenulisan ini akan ditemukan jawaban permasalahan sebagaimana tersebut pada bagian identifikasi masalah, yakni tentang hubungan pengawasan dengan penyelenggaraan otonomi luas.

Atas dasar keseluruhan uraian di atas dapat dikemukakan permasalahan yakni bagaimana re-evaluasi hubungan pengawasan Pusat terhadap Daerah dikaitkan dengan penyelenggaraan otonomi luas setelah berlakunya Undang-undang Nomor 23 Tahun 2014 tentang Pemerintahan Daerah. Tujuannya adalah untuk mengetahui, memahami dan menemukan politik hukum baru tentang hubungan Pusat dan Daerah mengenai pengawasan setelah berlakunya Undang-undang No. 23 Tahun 2014 tentang Pemerintahan Daerah. Metode yang digunakan dalam penelitian ini adalah yuridis normatif. Teknik analisis data yang digunakan adalah teknik analisis kualitatif dan deskriptif. Dengan demikian penelitian ini merupakan penelitian yuridis normatif. Data diolah secara kualitatif.

\section{Pembahasan}

\section{A. Hubungan Pengawasan Pusat Terhadap Daerah}

Ateng Syafrudin ${ }^{2}$ menyatakan pengawasan dalam kaitannya dengan penyelenggaraan pemerintahan daerah adalah suatu proses kegiatan yang ditujukan untuk menjamin agar pemerintahan daerah berjalan sesuai dengan rencana dan ketentuan perundang-undangan yang berlaku.

Secara umum ditinjau dari segi Hukum Administrasi Negara, pengawasan menurut pendapat Prajudi Atmosudirdjo ${ }^{3}$ diartikan sebagai proses kegiatan-kegiatan yang membandingkan apa yang dijalankan, dilaksanakan atau diselenggarakan itu dengan apa yang dikehendaki, direncanakan atau diperintahkan. Adapun menurut Sujamto ${ }^{4}$, pengawasan adalah segala usaha atau kegiatan untuk mengetahui dan menilai kenyataan yang sebenarnya mengenai pelaksanaan tugas sesuai dengan yang semestinya atau tidak.

Stephen Robein ${ }^{5}$ mendefinisikan pengawasan sebagai The process of monitoring activities to ensure they are being

2 Ateng Syafrudin, Naskah Lepas Masalah-masalah Hukum Otonomi Daerah (Arti Pengawasan), (Bandung: Program Pascasarjana Universitas Padjadjaran, 2003), hlm. 1.

3 Prajudi Atmosudirdjo, Hukum Administrasi Negara, (Jakarta: Ghalia Indonesia, 1983), hlm. 81.

4 Sujamto, Beberapa Pengertian di Bidang Pengawasan, (Jakarta: Ghalia Indonesia, 1986), hlm. 19.

5 W. Riawan Tjandra, Hukum Keuangan Negara, (Jakarta: Grasindo, 2009), hlm. 131. 
accomplished as planned and correcting any significant devisions. Secara bebas, maknanya adalah bahwa pengawasan merupakan suatu proses pengamatan terhadap suatu pekerjaan, untuk menjamin pekerjaan tersebut sesuai dengan yang direncanakan. Di dalamnya terdapat pengoreksian beberapa pemikiran yang saling berhubungan). Apabila menurut Black's Law Dictionary ${ }^{6}$, definisi pengawasan adalah:

\section{The direct or indirect power to} direct the management and policies of a person or entity, whether trouh ownership of voting securities, by contact, or otherwise; the power of authority to manage, direct, or overse (the principal exerdised control over the agent), or to exercise power or influence over (the judge controlled the proceedings), to regulate or govern by law.

Maknanya adalah bahwa pengawasan merupakan salah satu fungsi manajemen. Pengawasan ditujukan untuk memastikan suatu pelaksanaan kegiatan sesuai dengan rencana yang telah ditetapkan untuk pencapaian tujuan. Melalui pengawasan dapat dilakukan penilaian apakah suatu entitas telah melaksanakan kegiatan sesuai dengan tugas dan fungsinya secara efektif, efisien dan sesuai dengan ketentuan yang berlaku). ${ }^{7}$

\section{Pengawasan dan Pemerintahan Daerah}

Ada dua jenis pengawasan baku terhadap satuan pemerintahan otonom yaitu pengawasan preventif (preventief toezicht) dan pengawasan represif (repressief toezicht). Pengawasan ini berkaitan dengan produk hukum daerah dan tindakan tertentu organ pemerintahan daerah. Pengawasan preventif dikaitkan dengan wewenang mengesahkan (goedkeuring), Pengawasan represif adalah wewenang pembatalan (vernietiging) atau penangguhan(schorsing).

Peraturan daerah yang berlaku sebagai undang-undang bagi daerah, proses penyusunan maupun implementasinya perlu dipantau secara terus menerus untuk memberikan jaminan kepada publik bahwa semua ketentuan yang diatur dalam perda tersebut sudah mengikuti norma-norma/ kaidah-kaidah yang berlaku yaitu memenuhi persyaratan sebagai peraturan yang baik.

Ateng Syafrudin ${ }^{8}$ menyebutkan 3 (tiga) tujuan dari pelaksanaan pengawasan, berkenaan dengan penyelenggaraan tugastugas pemerintahan daerah, yakni;

1. Untuk menjaga kewibawaan pemerintah daerah dan kepentingannya;

2. Untuk menghindari atau mencegah penyalahgunaan wewenang;

6 Bryan A. Gamer, Black's Law Dictionary, Eight Edition, (St. Paul Minn: West, a Thomson Business, 2004), p. 353.

7 Redaksi Berita Transparansi, "Pengertian Pengawasan Keuangan Daerah dan Jenis-Jenisnya Menurut Para Ahli”, http://beritatransparansi.com/pengertian-pengawasan-keuangan-daerah-dan-jenis-jenisnya-menurutpara-ahli/, diakses 30 Desember 2016.

8 Ibid. 
3. Untuk mencegah kelalaian dalam administrasi yang dapat merugikan negara atau daerah.

Kriteria-kriteria di atas penting untuk menjadi pertimbangan dalam melakukan pengawasan, sehingga tujuan dari kegiatan pengawasan tersebut dapat tercapai. Paling tidak tujuan pengawasan itu adalah untuk mencegah sedini mungkin terjadinya penyimpangan, pemborosan, penyelewengan, hambatan, kesalahan dan kegagalan dalam pencapaian tujuan dan sasaran serta pelaksanaan tugas-tugas organisasi. ${ }^{9} \mathrm{H}$. Bohari mengatakan bahwa agar hal-hal tersebut tercapai maka harus menjaga agar rencana itu dalam realisasinya tetap terarah pada tujuan yang telah ditentukan dan menjaga agar pelaksanaannya itu dijalankan sesuai dengan peraturan-peraturan yang telah ditetapkan. Selain itu, perlu juga menjaga agar tugas itu dijalankan berdaya guna sesuai dengan tujuan dan melakukan usaha-usaha untuk mengatasi hambatan, mengendalikan penyimpanganpenyimpangan, serta akibat-akibatnya. ${ }^{10}$

Pengawasan dapat dibedakan menurut sifat/bentuk, tujuannya, ruang lingkupnya, dan metodenya. Beberapa macam pengertian pengawasan dapat diuraikan sebagai berikut. ${ }^{11}$

\section{a. Pengawasan menurut sifat atau bentuk dan tujuan}

Pengawasan menurut sifat/bentuk dan tujuannya dapat dikelompokan menjadi 2 (dua), yaitu: pengawasan preventif, dan pengawasan represif/pengawasan detektif. Pertama, Pengawasan Preventif. Pengawasan preventif dilakukan untuk mencegah terjadinya penyimpangan dalam pelaksanaan kegiatan. Dalam konteks pemerintahan daerah, pengawasan preventif mempunyai tujuan mencegah penyimpangan yang terjadi di lapangan pemerintahan daerah. Bagir Manan berpendapat bahwa pengawasan preventif ini berkaitan dengan wewenang mengesahkan (goedkeuring). ${ }^{12}$ Tujuan pengawasan preventif menurut Revrisond Baswir antara: mencegah terjadinya tindakantindakan yang menyimpang dari dasar yang telah ditentukan dan memberi pedoman bagi terselenggaranya pelaksanaan kegiatan secara efesien dan efektif. Selain itu juga untuk menentukan sasaran dan tujuan yang akan dicapai dan menentukan kewenangan dan tanggung jawab sebagai instansi sehubungan dengan tugas yang harus dilaksanakan. ${ }^{13}$ Kedua, Pengawasan Represif/Detektif. Prinsipnya, pengawasan dilaksanakan

9 Lembaga Administrasi Negara RI, op.cit., hlm. 159.

10 H. Bohari, Hukum Anggaran Negara, (Jakarta: Rajawali Pers. 1995), hlm. 117-118.

11 Elektison Somi, "Pengawasan Pengelolaan Keuangan Daerah dalam Sistem Pemerintahan Daerah di Indonesia", Disertasi Ilmu Hukum, Program Pascasarjana Doktor Ilmu Hukum, (Bandung: Universitas Padjadjaran, 2006), Tidak Dipublikasikan, hlm. 91-95.

12 Bagir Manan, Menyongsong Fajar Otonomi Daerah, (Yogyakarta: Pusat Studi Hukum (PSH), Fakultas Hukum UII, 2001), hlm. 154

13 Kerja Sama Antara Pusat Studi Kajian Negarafakultas Hukum Universitas Padjadjaran Bandung, "Penelitian Pola Hubungan Antara Pusat Dan Daerah", https://www.scribd.com/doc/66370233/Pola-Hubungan-AntaraPusat-Dan-Daerah-UNPAD, diakses 20 Januari 2017. 
setelah dilakukannya tindakan yakni dengan membandingkan antara hal yang telah terjadi dengan hal yang direncanakan terjadi. Dalam hal pembentukan produk hukum daerah dan tindakan tertentu organ pemerintah daerah, pengawasan ini menurut Bagir Manan berupa wewenang pembatalan (Verneitiging) atau penangguhan (schorsing). ${ }^{14}$

Paulus Effendie Lotulung menyatakan bahwa salah satu permasalahan pokok dalam studi tentang dasar-dasar hukum Administrasi adalah pelajaran tentang berbagai macam kontrol atau pengawasan yang dapat dilakukan terhadap Pemerintah. Pemerintah selaku organ administarasi Negara dapat dikenakan bermacam-macam bentuk kontrol atau pengawasan dalam melaksanakan tugas atau "mission"nya untuk menyelenggarakan kesejahteraan umum dan pelayanan kepentingan umum (public service). Tujuan pokok dari kontrol ini adalah untuk menghindari terjadinya kekeliruan, baik yang disengaja maupun tidak disengaja, sebagai suatu usaha preventif. Selain itu juga untuk memperbaikinya apabila sudah terjadi kekeliruan itu, sebagai suatu usaha represif. Dalam praktik, adanya pengawasan itu sering dilihat sebagai sarana unutuk mencegah terjadinya bentuk penyimpangan tugas pemerintahan dari apa yang telah direncanakan. Memang di sinilah letak inti atau hakekat dari suatu pengawasan. ${ }^{15}$
Berdasarkan kedudukan dari badan/organ yang melaksanakan kontrol terhadap badan/ organ yang dikontrol, kontrol dapat dibedakan menjadi Kontrol Intern dan Kontrol Ekstern. Kontrol Intern merupakan suatu pengawasan yang dilakukan oleh suatu badan yang secara oraganisatoris/struktural dalam lingkungan Pemerintah sendiri. Misalnya pengawasan yang dilakukan oleh pejabat atasan terhadap bawahannya secara hierarkis, ataupun pengawasan yang dilakukan oleh suatu tim yang dibentuk secara insidentil dari ahli dalam bidang-bidang tertentu. Bentuk kontrol semacam itu dapat digolongkan dalanm jenis kontrol teknis-administratif (built-in control).

Sebaliknya, suatu Kontrol Ekstern merupakan pengawasan oleh organ atau lembaga yang secara organisatoris/struktural berada di luar Pemerintah (eksekutif). Misalnya kontrol keuangan yang dilakukan oleh Badan Pengawas Keuangan, kontrol sosial yang dilakukan melalui pers/mas media, kontrol politis yang dilakukan oleh lembaga perwakilan rakyat dalam bentuk dengar pendapat ataupun hak bertanya para anggotanya. Kontrol ekstern ini termasuk pula kontrol yang dilakukan secara tidak langsung melalui badan peradilan (judicial control). ${ }^{16}$

Ditinjau dari segi waktu pelaksanaan kontrol atau pengawasan, kontrol dapat dibedakan dalam 2 jenis yakni Kontrol a-priori dan Kontrol a-posteriori. Kontrol a-priori

\footnotetext{
14 Bagir Manan, loc.cit.

15 Paulus Effendie Lotulung, Beberapa Sistem tentang Kontrol Segi Hukum terhadap Pemarintah, (Jakarta: Bhuana Ilmu Populer, 1986), hlm. xv.

16 Ibid., hlm. xvi.
} 
adalah bila pengawasan itu dilakukan sebelum dikeluarkannya suatu keputusan atau ketetapan Pemerintah ataupun peraturan lainnya. Dalam hal ini tampak jelas unsur preventifnya. Tujuan utamanya adalah untuk mencegah atau menghindari terjadinya kekeliruan. Sebagai contoh: pengeluaran suatu yang untuk berlaku sah dan dilaksanakan, harus terlebih dahulu memperoleh persetujuan dan pengesahan dari instansi atasan. Selanjutnya, Kontrol a-posteriori merupakan pengawasan yang baru terjadi sesudah dikeluarkannya keputusan/ketetapan Pemerintah atau sesudah terjadinya tindakan/perbuatan Pemerintah. Pengawasan ini menitikberatkan kepada tujuan yang bersifat korektif dan memulihkan suatu tindakan yang keliru. Peranan badan peradilan melalui suatu judicial control adalah selalu bersifat Kontrol a-posteriori, karena selalu dilakukan sesudah terjadinya sustu perbuatan atau tindakan.

Pembedaan pengawasan juga bisa dilakukan dari segi sifat kontrol itu terhadap objek yang diawasi. Apakah kontrol itu hanya dimaksudkan untuk menilai segi-segi atau pertimbangan yang bersifat hukumnya atau segi legalitas, yaitu segi "rechtmatigheid" atau perbuatan itu ditinjau dari segi kemanfaatannya "doelmatigheid". Misalnya: Kontrol yang dilakukan oleh badan peradilan pada prinsipnya hanya menitikberatkan pada segi legalitas, yaitu kontrol segi hukum. Sedangkan suatu kontrol teknis administratif intern dalam lingkungan Pemerintah sendiri/ built-in control bersifat selain penilaian legalitas (rechtsmatigsheidtoetsing) juga dan bahkan lebih menitikberatkan pada segi penilaian kemanfaatan. ${ }^{17}$ Di lapangan pemerintahan daerah, instrument pengawasan, baik yang bersifat preventif maupun yang bersifat represif seringkali digunakan.

\section{Kedudukan dekonsentrasi dalam penyelenggaraan Pemerintahan Daerah}

Dalam UUD Tahun 1945, baik sebelum perubahan maupun setelah perubahan ternyata asas dekonsentrasi tidak diatur secara eksplisit. Namun demikian, bahwa pada saat pembahasan Pasal 18 UUD Tahun 1945, para perumus undang-undang dasar telah membicarakan secara mendalam tentang dekonsentrasi dalam rangka penyelenggaraan pemerintahan di negara yang akan dibentuk. Seperti Amir dan Ratulangie ${ }^{18}$, mengatakan bahwa dekonsentrasi itu perlu diadakan dalam rangka penyelenggaraan otonomi daerah dan dicantumkan di dalam UUD 1945. Sementara Soepomo mengatakan hal tersebut memang perlu diatur, namun akan dilakukan dalam undang-undang tersendiri.

Dekonsentrasi itu hidup dalam praktik penyelenggaraan pemerintahan daerah di Indonesia. Penganut paham positivisme, tentu tidak akan sepakat dengan cara-cara penyelenggaraan seperti ini, yaitu asas 
dekonsentrasi tidak dcantumkan secara tegas di dalam UUD 1945. Akan tetapi bagi para penganut paham sosiological-jurisprudence atau paham sosiologis misalnya tentu mendukung cara-cara penyelenggaraan pemerintahan tersebut. Tugas para pelaksana hukum (Pemerintah) atau penegak hukum adalah menggali hukum baik berupa nilainilai maupun asas-asas hukum yang ada dan berkembang di dalam masyarakat (praktik).

Pasal 18 ayat (2) UUD 1945 (hasil perubahan kedua) menyatakan, bahwa:

Pemerintahan daerah provinsi, daerah kabupaten, dan kota mengatur urusan pemerintahan menurut asas otonomi dan tugas pembantuan.

Jimly Asshiddiqie mengemukakan, bahwa asas pemerintahan daerah secara universal selalu dipahami mencakup tiga asas penting, yaitu $^{19}$ :

a. asas desentralisasi;

b. asas dekonsentrasi;

c. asas tugas perbantuan.

Di dalam Pasal 18 ayat (2) UUD 1945 tersebut, asas desentralisasi disebut asas otonomi, dan asas dekonsentrasi tidak dicantumkan secara eksplisit. Menurut Bagir Manan, Pasal 18 ini secara keseluruhan mengatur tentang pemerintahan daerah, bukan mengaturpemerintahan pusat. Karena itu, tidak tercantumnya perkataan 'asas dekonsentrasi' dalam ayat ini tidak perlu dipahami bahwa asas dekonsentrasi itu tidak boleh ada dalam sistem pemerintahan di daerah. Oleh karena asas dekonsentrasi itu merupakan kewenangan pemerintah pusat, maka dengan sendirinya jika pemerintah pusat menganggapnya perlu, kegiatan-kegiatan yang berkaitan dengan asas dekonsentrasi itu dapat saja dilakukan oleh pemerintah pusat. Namun, terhadap pendapat ini diajukan kritik. Pertama, diakuinya bahwa asas dekonsentrasi itu ada dan juga dianut dalam UUD 1945 setelah diubah, seharusnya tidak hanya didasarkan atas doktrin ilmu pengetahuan, melainkan harus dicantumkan secara tegas dalam pasal UUD. Kedua, asas dekonsentrasi dan tugas pembantuan samasama menyangkut kewenangan pemerintah pusat, dan sama-sama bersifat teknis, tetapi 'asas tugas pembantuan' dicantumkan dengan tegas di dalam Pasal 18 ayat (2) UUD 1945, disisi yang lain asas 'dekonsentrasi' tidak dicantumkan ${ }^{20}$. Penulis sependapat dengan Jimly Asshiddiqie yang mengatakan bahwa penghapusan asas dekonsentrasi dari rumusan asas pemerintahan daerah dapat menimbulkan penafsiran bahwa UUD 1945 memang bermaksud meniadakan asas dekonsentrasi itu sama sekali. Akibatnya, mekanisme penyelenggaraan dan pengelolaan organisasi pemerintahan daerah dapat berkembang ke arah pengertian 'federal arrangement'. Dengan demikian, bentuk negara Indonesia dapat dikatan sebagai negara kesatuan dengan federal arrangement ${ }^{21}$.

Terkait dekonsentrasi, Laica Marzuki berpendapat bahwa dekonsentrasi merupakan

19 Jimly Asshiddiqie, Konsolidasi Naskah...., op.cit., hlm. 21.

20 Jimly Asshiddiqie, Konsolidasi Naskah ...., Ibid., hlm. 21-22.

21 Loc.cit., hlm. 22. 
ambtelijke decentralisatie atau delegatie van bevoegheid. Artinya, pelimpahan kewenangan dari alat kelengkapan negara di pusat kepada instansi bawahan untuk melaksanakan pekerjaan tertentu dalam bidang penyelenggaraan pemerintahan. Instansi bawahan melaksanakan tugas atas nama pemerintah pusat sehingga pemerintah pusat melalui dekonsentrasi tidak kehilangan kewenangannya ${ }^{22}$. Dekonsentrasi juga bermaknasebagaipenyebaranataupemencaran kewenangan pusat kepada petugasnya di wilayah-wilayah untuk melaksanakan kebijaksanaan pusat. Pemberian wewenang dekonsentrasi hanya bersifat menjalankan atau melaksanakan keputusan dan peraturan yang berasal dari pemerintah pusat agar penyelenggaraan pemerintahan daerah dapat berjalan sesuai dengan prinsip dan tujuan otonomi daerah.

\section{Hubungan pusat dan daerah}

Secara teoritis hubungan pusat dan daerah meliputi hubungan kewenangan, hubungan keuangan dan hubungan pengawasan. Dalam UUD 1945 hubungan pusat dan daerah mencakup hubungan wewenang, keuangan, pelayanan umum, sumber daya alam, dan sumber daya lainnya. Urusan Pemerintahan yang diserahkan ke Daerah berasal dari kekuasaan pemerintahan yang ada pada Presiden.

Konsekuensi suatu negara kesatuan adalah tanggung jawab akhir pemerintahan ada ditangan Presiden. Presiden sebagai pemegang kekuasaan pemerintahan dibantu oleh menteri dan setiap menteri bertanggung jawab atas Urusan Pemerintahan tertentu dalam pemerintahan. Presiden melakukan pembinaan dan pengawasan terhadap penyelenggaraan Pemerintahan Daerah agar pelaksanaan Urusan Pemerintahan yang diserahkan ke Daerah berjalan sesuai dengan kebijakan nasional.

Aparat Pengawas Internal Pemerintah adalah inspektorat jenderal kementerian, unit pengawasan lembaga pemerintah nonkementerian, inspektorat provinsi, dan inspektorat kabupaten/kota.

Mengenai pengaturan pembinaan dan pengawasan, Undang-Undang No. 23 Tahun 2014 mengatur dalam Bab XIX Pasal 373 sampai dengan Pasal 383. Pemerintah Pusat melakukan pembinaan dan pengawasan terhadap penyelenggaraan Pemerintahan Daerah provinsi. Gubernur sebagai wakil Pemerintah Pusat melakukan pembinaan dan pengawasan terhadap penyelenggaraan Pemerintahan Daerah kabupaten/kota. Pembinaan dan pengawasan secara nasional dikoordinasikan oleh Menteri.

Pembinaan terhadap penyelenggaraan Pemerintahan Daerah provinsi dilaksanakan oleh Menteri, menteri teknis, dan kepala lembaga pemerintah nonkementerian. Menteri melakukan pembinaan yang bersifat umum meliputi: pembagian Urusan Pemerintahan, 
kelembagaan Daerah, kepala Daerah dan DPRD, kepegawaian pada Perangkat Daerah, kerja sama Daerah, pembangunan Daerah, pelayanan publik di Daerah, kebijakan Daerah, keuangan Daerah; dan bentuk pembinaan lain sesuai peraturan perundang-undangan. Menteri teknis dan kepala lembaga pemerintah non-Kementerian melakukan pembinaan yang bersifat teknis penyelenggaraan Urusan Pemerintahan yang diserahkan ke Daerah provinsi. Pembinaan yang bersifat umum dan teknis dilakukan dalam bentuk fasilitasi, konsultasi, penelitian dan pengembangan serta pendidikan dan pelatihan.

Pembinaan terhadap Pemerintahan Daerah kabupaten/kota dilaksanakan oleh gubernur sebagai wakil Pemerintah Pusat. Dalam melakukan pembinaan gubernur selaku wakil Pemerintah Pusat melakukan pembinaan yang bersifat umum dan bersifat teknis. Gubernur sebagai wakil Pemerintah Pusat melakukan pembinaan yang bersifat umum terhadap: pelayanan publik di Daerah, keuangan Daerah, kepala daerah dan DPRD, pembagian Urusan Pemerintahan, kelembagaan Daerah, kepegawaian pada Perangkat Daerah, pembangunan Daerah, kerja sama Daerah, kebijakan Daerah; dan bentuk pembinaan lain sesuai peraturan perundang-undangan.

Gubernur sebagai wakil Pemerintah Pusat melakukan pembinaan yang bersifat teknis terhadap teknis penyelenggaraan Urusan Pemerintahan yang diserahkan ke Daerah kabupaten/kota. Pembinaan Gubernur yang bersifat umum dan teknis dilakukan dalam bentuk fasilitasi, konsultasi, pendidikan dan pelatihan serta penelitian. Termasuk pula pengembangan dalam kebijakan yang terkait dengan Otonomi Daerah. Pemerintah Pusat melaksanakan pembinaan kepada Daerah kabupaten/kota dengan berkoordinasi kepada gubernur sebagai wakil Pemerintah Pusat dalam hal gubernur sebagai wakil Pemerintah Pusat belum mampu melakukan pembinaan.

Dalam melaksanakan pembinaan dan pengawasan, gubernur dibantu oleh inspektorat provinsi. Bupati/wali kota sebagai kepala daerah kabupaten/kota wajib melaksanakan pembinaan dan pengawasan terhadap Perangkat Daerah kabupaten/ kota. Dalam melaksanakan pembinaan dan pengawasan, bupati/wali kota dibantu oleh inspektorat kabupaten/kota.

Pusat melakukan penyusunan indeks dan peringkat kinerja penyelenggaraan Pemerintah Daerah untuk bahan evaluasi setiap tahun. Daerah provinsi yang menurut hasil evaluasi penyelenggaraan Pemerintahan Daerah mempunyai kinerja rendah maka Menteri, menteri teknis, dan kepala lembaga pemerintah nonkementerian melakukan pembinaan terhadap penyelenggaraan Urusan Pemerintahan tertentu yang menjadi kewenangan Daerah. ${ }^{23}$ Menteri melakukan fasilitasi khusus terhadap penyelenggaraan Pemerintahan Daerah provinsi yang telah

23 Course Hero, "2 dalam 2012 dalam melaksanakan pembinaan dan Pengawasan-pengawasan sebagaimana dimaksud", https://www.coursehero.com/file/p3ncika4/2-Dalam-201-2-Dalam-melaksanakan-pembinaandan-pengawasan-sebagaimana-dimaksud/, diakses 20 Januari 2017. 
dibina namun tidak menunjukkan perbaikan kinerja. Fasilitasi khusus dilakukan jika penyelenggaraan Urusan Pemerintahan tertentu yang menjadi kewenangan Daerah yang berkinerja rendah namun tidak berpotensi merugikan kepentingan umum secara meluas. Menteri dalam melakukan fasilitasi khusus berkoordinasi dengan menteri teknis dan kepala lembaga pemerintah nonkementerian. Gubernur sebagai wakil Pemerintah Pusat melakukan fasilitasi khusus kepada penyelenggaraan Pemerintah Daerah kabupaten/kota yang telah dibina namun tidak menunjukkan perbaikan kinerja. Dalam hal Daerah provinsi dan Daerah kabupaten/kota yang sudah dibina tidak menunjukkan perbaikan kinerja dan berpotensi merugikan kepentingan umum secara meluas, Pemerintah Pusat melakukan pengambilalihan pelaksanaan Urusan Pemerintahan tertentu atas biaya yang diperhitungkan dari APBD yang bersangkutan. Pemerintah Pusat dapat melimpahkan kepada gubernur sebagai wakil Pemerintah Pusat untuk melaksanakan Urusan Pemerintahan yang menjadi kewenangan Daerah kabupaten/kota yang diambil alih oleh Pemerintah Pusat.

Adapun Data Tentang Pelaksanaan Pengawasan Pusat Terhadap Daerah Melalui Pembatalan Perda Sebelum Dan Sesudah Berlakunya Undang-undang Nomor 23 Tahun 2014 Tentang Pemerintahan Daerah, dapat diuraikan sebagai berikut:

1. Pembatalan Perda Sebelum Berlakunya Undang-undang Nomor 23 Tahun 2014 Tentang Pemerintahan Daerah, dapat dilihat pada Tabel 1 di bawah ini:

Tabel 1. Jumlah Pembatalan Perda Sebelum UU No. 23 Tahun 2014

\begin{tabular}{ccc}
\hline No. & Tahun & Jumlah Perda \\
\hline 1. & 2002 & 19 \\
2. & 2003 & 105 \\
3. & 2004 & 236 \\
4. & 2005 & 126 \\
5. & 2006 & 114 \\
6. & 2007 & 173 \\
7. & 2008 & 229 \\
8. & 2009 & 715 \\
\hline Jumlah Keseluruhan & 1717 \\
\hline
\end{tabular}

Sumber: https://www.scribd.com/document/320418140/UNDANG-UNDANGREPUBLIK-INDONESIA-NO-9-TAHUN-2015-pdf. 
2. Pembatalan Perda Setelah Berlakunya Undang-undang Nomor 23 Tahun 2014

Tentang Pemerintahan Daerah

Terhitung sejak November 2014 hingga Mei 2015, Kementerian Dalam Negeri telah membatalkan 139 (seratus tia puluh Sembilan) peraturan daerah. Perda-perda yang dibatalkan tersebut dianggap bertentangan dengan undang-undang atau prinsip negara kesatuan Republik Indonesia. ${ }^{24}$ Pada tahun
2016 Kemendagri secara resmi telah membatalkan sebanyak 3.143, di antaranya ada 1765 Perda/Perkada kabupaten/kota yang dicabut/direvisi Menteri Dalam Negeri, 111 Peraturan/keputusan Menteri Dalam Negeri yang dicabut/revisi oleh Menteri Dalam Negeri, dan 1267 Perda/Perkada kabupaten/ kota yang dicabut/direvisi Gubernur ${ }^{25}$.

Mengenai pengawasan preventif dan represif terhadap Perda, hasil penelitian dapat dilihat dalam Tabel 2. di bawah ini:

\section{Tabel 2. Bentuk Pengawasan Preventif dan Represif Terhadap Perda}

\begin{tabular}{cl}
\hline No. & \multicolumn{1}{c}{ Bentuk Pengawasan } \\
\hline 1 & $\begin{array}{l}\text { Kewenangan Presiden dalam melakukan pengawasan terhadap Perda didelegasikan } \\
\text { kepada Gubernur sebagai Wakil Pemerintah Pusat Di Daerah. }\end{array}$ \\
2 & $\begin{array}{l}\text { Kalau ada keberatan terhadap pembatalan/penangguhan Perda, Keputusan Presiden } \\
\text { atas keberatan tersebut bersifat final. }\end{array}$ \\
3 & $\begin{array}{l}\text { Ketentuan saat ini, Perda yang telah ditetapkan harus selalu diberi Nomor Register } \\
\text { dalam rangka pengawasan preventif. }\end{array}$ \\
\hline
\end{tabular}

Sumber: diolah dari bahan hukum primer, 2017

\section{B. Penyelenggaraan Pemerintahan Daerah}

Kepala daerah dan DPRD selaku penyelenggara Pemerintahan Daerah dalam melaksanakan Urusan Pemerintahan yang menjadi kewenangan Daerah menetapkan Perda sesuai dengan kondisi dan aspirasi masyarakat serta kekhasan dari Daerah tersebut. Perda berlaku dalam batas-batas wilayah Daerah yang bersangkutan. Perda yang ditetapkan oleh Daerah tidak boleh bertentangan dengan ketentuan peraturan perundangundangan yang lebih tinggi. Perda sebagai bagian dari sistem peraturan perundang-undangan tidak boleh bertentangan dengan kepentingan umum. Dalam koteks pembataan perda, seharusnya didudukkan bahwa tanggung jawab akhir penyelenggaraan pemerintahan ada di tangan Presiden. Konsekwensi logisnya adalah kewenangan

24 Kompas Jakarta, "Sejak November 2014 hingga Mei 2015, Mendagri Batalkan 139 Perda", http://nasional. kompas.com/read/2015/07/22/17054251/Sejak.November.2014.hingga.Mei.2015.Mendagri.Batalkan.139. Perda, diakses 15 November 2015.

25 Kemendagri, "Daftar Pembatalan 3.143 Perda Masih Perlu Penyempurnaan", http://www.kemendagri.go.id/ news/2016/06/21/daftar-pembatalan-3143-perda-masih-perlu-penyempurnaan, diakses 15 November 2015. 
untuk melakukan pengawasan yang adalam hal ini membatalkan Perda (pengawasan represif) seharusnya ada ditangan Presiden. ${ }^{26}$

\section{Pengaturan dan Pelaksanaan Pembinaan dan Pengawasan Sebelum Berlakunya Undang- undang No. 23 Tahun 2014 Jo. Undang-undang No. 5 Tahun 2012}

Menurut UU Nomor 32 Tahun 2004 (UU yang telah diganti oleh UU No.23 Tahun 2014), pengawasan atas penyelenggaraan pemerintahan daerah adalah proses kegiatan yang ditujukan untuk menjamin agar pemerintah daerah berjalan sesuai dengan rencana dan ketentuan peraturan perundangundangan yang berlaku.

Pengawasan terhadap rancangan peraturan daerah dan peraturan daerah, Pemerintah melakukan dengan 2 (dua) cara sebagai berikut: ${ }^{27}$

a. Pengawasan terhadap rancangan peraturan daerah (RAPERDA), yaitu terhadap rancangan peraturan daerah yang mengatur pajak daerah, retribusi daerah, APBD, dan RUTR.

b. Pengawasan terhadap semua peraturan daerah di luar yang termasuk dalam angka 1, yaitu setiap peraturan daerah wajib disampaikan kepada Menteri Dalam Negeri untuk provinsi dan Gubernur untuk kabupaten/kota untuk memperoleh klarifikasi.
2. Pengaturan, pelaksanaan pembinaan dan pengawasan menurut Undang-undang No. 23 Tahun 2014

Adapun yang berkaitan dengan masalah hubungan pengawasan Pusat dan Daerah menurut Undang-Undang No. 23 Tahun 2014, diatur peran Gubernur dalam melakukan pengawasan sebagai Wakil Pemerintah Pusat di Daerah. Mengingat kondisi geografis yang sangat luas, maka untuk efektifitas dan efisiensi pembinaan dan pengawasan atas penyelenggaraan Urusan Pemerintahan yang menjadi kewenangan Daerah kabupaten/ kota, Presiden sebagai penanggung jawab akhir melimpahkan/mendelegasikan kewenangannya kepada Gubernur sebagai Wakil Pemerintah Pusat di Daerah.

Gubernur sebagai Wakil Pemerintah Pusat di Daerah itu berkaitan dengan pelaksanaan asas dekonsentrasi. Dekonsentrasi merupakan pelimpahan sebagian Urusan Pemerintah Pusat kepada gubernur sebagai wakil Pemerintah Pusat, kepada instansi vertikal di wilayah tertentu, dan/atau kepada gubernur dan bupati/wali kota sebagai penanggung jawab urusan pemerintahan umum. ${ }^{28}$ Urusan pemerintahan umum menjadi kewenangan Presiden yang meliputi pemeliharaan ideologi Pancasila, UUD 1945, Bhinneka Tunggal Ika, menjamin hubungan yang serasi berdasarkan suku, agama, ras dan antar golongan serta

26 Undang-Undang Republik Indonesia, "Pemerintahan Daerah (UU 23-2014 Beserta Perubahan)" https://www. scribd.com/document/324076805/Pemerintahan-Daerah-UU-23-2014-Beserta-Perubahan, diakses 20 Januari 2017.

27 Lihat Penjelasan Umum angka 9 UU Nomor 32 Tahun 2004.

28 Pasal 1 Butir 9 Undang-undang Nomor 23 Tahun 2014 tentang Pemerintahan Daerah. 
memfasilitasi kehidupan demokratis. Gubernur sebagai kepala pemerintahan provinsi dan kepada bupati/wali kota sebagai kepala pemerintahan kabupaten/kota diberi pelimbahan wewenang oleh Presiden dalam pelaksanaan urusan pemerintahan umum di Daerah. Dengan demikian, berbeda dengan UU Pemerintahan Daerah sebelumnya, UU No. 23 Tahun 2014 berkaitan dengan pengawasan Pusat terhadap Daerah, mengatur secara tegas asas dekonsentrasi dan urusan pemerintahan umum.

\section{Simpulan}

Berdasarkan uraian hasil dan pembahasan maka dapat diperoleh simpulan sebagai berikut:

1. Setelah berlakunya Undang-undang No. 23 Tahun 2014 tentang Pemerintahan Daerah telah terjadi perubahan politik hukum pengawasan Pusat terhadap Daerah. Berbeda dengan UU Pemerintahan Daerah sebelumnya, UU No.23 Tahun 2014 berkaitan dengan pengawasan Pusat terhadap Daerah, mengatur secara tegas asas dekonsentrasi dan urusan pemerintahan umum.

2. Pembinaan dan pengawasan terhadap penyelengaraan pemerintahan daerah sebagaimanadiaturolehUUPemerintahan Daerah yang baru (UU No. 23 Tahun 2014) dalam pelaksanaannya tidak mengurangi/membelenggu kemandirian daerah dan tidak menghambat pembangunan di daerah serta tetap sejalan dengan penyelenggaraan otonomi seluasluasnya. Materi pokok pengawasan Pusat terhadap Daerah mencakup hal-hal sebagai berikut:

a. Pengertian dan ruang lingkup pengawasan Pusat terhadap Daerah;

b. Pengawasan dan Pemerintahan Daerah;

c. Kedudukan dekonsentrasi dalam penyelenggaraan Pemerintahan Daerah;

d. Data tentang pelaksanaan pengawasan Pusat terhadap Daerah melalui Pembatalan Perda sebelum dan sesudah berlakunya Undang-undang Nomor 23 Tahun 2014 Tentang Pemerintahan Daerah.

\section{DAFTAR PUSTAKA}

\section{Buku}

Atmosudirdjo, Prajudi. Hukum Administrasi

Negara. Jakarta: Ghalia Indonesia, 1983.

D., Rondinelli, and Cheema, G. Decentralization and Development:
Policy Implementation in Developing Countries. Beverly Hills: Sage Publication, 1983.

Fachruddin, Irfan. Pengawasan Peradilan Administrasi Terhadap Tindakan Pemerintah. Bandung: Alumni, 2004. 
Gadjong, Agussalim Andi. Pemerintahan

Daerah: Kajian Politik dan Hukum. Ghalia Bogor: Indonesia, 2007.

Manan, Bagir. Perjalanan Historis Pasal 18 UUD 1945 (Perumusan dan Undangundang Pelaksanaannya. Karawang: Unsika, 1993.

Menyongsong Fajar

Otonomi Daerah. Yogyakarta: Pusat Studi Hukum (PSH), Fakultas Hukum UII, 2002.

Muslimin, Amrah. Aspek-aspek Hukum Otonomi Daerah. Bandung: Alumni, 1987.

Suryaningat, Bayu. Desentralisasi dan Dekonsentrasi Pemerintahan di Indonesia Suatu Analisa. Jakarta: Dewa Ruci Press, 1981.

Syafrudin, Ateng. Pasang Surut Otonomi Daerah. Bandung: Binacipta, 1985. - Kapita Selekta, Hakikat

Otonomi \& Desentralisasi Dalam Pembangunan Daerah. Yogyakarta:

Citra Media, 2006. Mengarungi Dua

Samudera, Setengah Abad Pemikiran Seorang Pamongpraja \& Ilmuwan Hukum Tata Pemerintahan. Bandung: Sayagatama, 2006. . Naskah Lepas Masalahmasalah Hukum Otonomi Daerah (Arti Pengawasan). Bandung: Program Pascasarjana Universitas Padjadjaran, 2003.
Pelaksanaan

Desentralisasi dan Dekonsentrasi Pemerintahan. Bandung, Singa Marga, Tanpa Tahun.

Dekonsentrasi. Bandung: Refika Aditama, 2006. - Pengaturan Koordinasi

Pemerintahan Di Daerah. Bandung: Citra Aditya Bakti, 1993.

Pemerintahan Daerah Di Jepang. Bandung: Refika Aditama, 2006.

\section{Disertasi}

Somi, Elektison. "Pengawasan Pengelolaan Keuangan Daerah dalam Sistem Pemerintahan Daerah di Indonesia". Disertasi Ilmu Hukum, Program Pascasarjana Doktor Ilmu Hukum. Bandung: Universitas Padjadjaran, 2006. Tidak Dipublikasikan. hlm. 91-95.

\section{Peraturan Perundang-undangan}

Keputusan Menteri Dalam Negeri Nomor 29 Tahun 2002 tentang Pedoman Pengurusan, Pertanggungjawaban dan Pengawasan Keuangan Daerah serta Tata Cara Penyusunan Anggaran Pendapatan dan Belanja Daerah, Pelaksanaan Tata Usaha Keuangan Daerah dan Penyusunan Perhitungan Anggaran Pendapatan dan Belanja Daerah. 
Keputusan Presiden Nomor 74 Tahun 2001 tentang Tata Cara Pengawasan Penyelenggaraan Pemerintahan Daerah.

Ketetapan MPR-RI No. X/MPR/1996 tentang Pokok-pokok reformasi Pembangunan dalam rangka penyelamatan dan normalisasi kehidupan nasional sebagai haluan negara.

Ketetapan MPR-RI Nomor XV/MPR/1998 tentang Penyelenggaraan Otonomi Daerah, Pengaturan, Pembagian dan Pemanfaatan sumber daya nasional yang berkeadilan, serta pembagian Keuangan Pusat dan Daerah dalam rangka kerangka Negara Kesatuan Republik Indonesia.

Peraturan Menteri Dalam Negeri Nomor 80 Tahun 2015 tentang Pembentukan Produk Hukum Daerah.

Peraturan Pemerintah Nomor 20 Tahun 2001 tentang Pembinaan dan Pengawasan Atas Penyelenggaraan Pemerintah Daerah.

Peraturan Pemerintah Nomor 7 Tahun 2008 tentang Dekonsentrasi Dan Tugas Pembantuan.

Peraturan Pemerintah Nomor 79 Tahun 2005 tentang Pedoman Pembinaan dan Pengawasan Penyelenggaraan Pemerintah Daerah.

Peraturan Pemerintah Republik Indonesia Nomor 38 Tahun 2007 tentang Pembagian Urusan Pemerintahan antara Pemerintah, Pemerintahan
Daerah Provinsi, Dan Pemerintahan Daerah Kabupaten/Kota.

Peraturan Pemerintah Republik Indonesia Nomor 39 Tahun 2001 tentang Penyelenggaraan Dekonsentrasi.

Undang-undang Dasar Negara Republik Indonesia 1945.

Undang-undang Nomor 23 Tahun 2014 tentang Pemerintahan Daerah yang telah direvisi oleh UU No. 2 Tahun 2015.

Undang-undang Nomor 32 Tahun 2004 tentang Pemerintahan Daerah.

Undang-undang Nomor 8 Tahun 2005 tentang Penetapan Peraturan Pemerintah Pengganti Undang-undang Nomor 3 Tahun 2005 tentang Perubahan Atas Undang-undang Nomor 32 Tahun 2004 tentang Pemerintahan Daerah menjadi Undang-undang.

\section{Naskah Internet}

Kerja Sama Antara Pusat Studi Kajian Negarafakultas Hukum Universitas Padjadjaran Bandung. "Penelitian Pola Hubungan Antara Pusat Dan Daerah". https://www.scribd.com/ doc/66370233/Pola-Hubungan-AntaraPusat-Dan-Daerah-UNPAD. Diakses 20 Januari 2017.

Kompas Jakarta. "Sejak November 2014 hingga Mei 2015, Mendagri Batalkan 139 Perda". http://nasional.kompas. com/read/2015/07/22/17054251/Sejak. November.2014.hingga.Mei.2015. Mendagri.Batalkan.139.Perda. Diakses 
15 November 2015.

Redaksi Berita Transparansi. "Pengertian Pengawasan Keuangan Daerah dan Jenis-Jenisnya Menurut Para Ahli”. http://beritatransparansi.com/ pengertian-pengawasan-keuangan- daerah-dan-jenis-jenisnya-menurutpara-ahli/. Diakses 30 Desember 2016.

\section{Kamus}

Gamer, Bryan A. Black's Law Dictionary. Eight Edition. St. Paul Minn: West, a Thomson Business, 2004. 